EASTERN REVIEW 2018, T. 7

\author{
Jacek Pokładecki
}

\title{
Partycypacja a lokalny system polityczny
}

Funkcjonowanie lokalnego systemu politycznego w Polsce ustrojowo wiąże się bezpośrednio z instytucją samorządu terytorialnego, który niezależnie od sposobu jego definiowania jest immamentnym elementem demokratycznego państwa. Samorząd terytorialny jest ,szczególną postacią władzy publicznej, wiążącej lokalną społeczność i działające na jej rzecz instytucje lokalne w jedną, spójną całość, którą można by nazwać lokalnym systemem politycznym"”. Tym samym „organizacje samorządowe są [...] kluczowym narzędziem codziennej realizacji ustroju demokratycznego", spełniając misję polityczną, którą jest „tworzenie warunków dla realizowania idei wolności obywatelskiej i przeciwdziałania alienacji władzy” oraz misję gospodarczą, a więc „dbałość, o jakość życia mieszkańców poprzez dostarczanie usług publicznych i dbałość o rozwój ekonomiczny". Wspólnym dla tych misji jest ich podporządkowanie realizacji interesu publicznego, co wymaga realnej partycypacji mieszkańców w działaniach samorządu terytorialnego ${ }^{2}$.

W odniesieniu do społeczności lokalnych pojęcie interesu publicznego, przy wszystkich problemach z jego określeniem, należy wiązać z korzyściami odnoszonymi przez ogół mieszkańców. Samo pojęcie ogółu ma jednak wymiar idealistyczny. Zachowując określoną dozę sceptycyzmu i odnosząc się do empirycznego oglądu rzeczywistości, przyjąć należy, że im większa zbiorowość korzysta $z$ danego rozstrzygnięcia, tym bardziej zasługuje ono na uznanie, iż jest zgodne $\mathrm{z}$ interesem publicznym ${ }^{3}$. Administracja publiczna, sprawowana zarówno przez

${ }^{1}$ A. Antoszewski, Istota władzy samorzadowej, [w:] Polityka lokalna. Właściwości determinanty, podmioty, red. E. Ganowicz, L. Rubisz, Toruń 2008, s. 43.

2 J.T. Hryniewicz, Analiza funkcjonowania samorzadu lokalnego w oparciu o kluczowe kategorie nauk o zarządzaniu: misje, cele, własność, kontekst organizacyjny i efektywność, [w:] 20 lat samorzadu terytorialnego w Polsce. Sukcesy, porażki, perspektywy, red. K. Mieczkowska-Czerniak, K. Radzik-Maruszak, Lublin 2012, s. 79-95.

${ }^{3}$ Ibidem, s. 81-82. 
państwo, jak i jednostki samorządu terytorialnego, realizować ma dobro wspólne, czyli interes publiczny po to, by przynieść określoną korzyść ogółowi, ale też zadbać o optymalizację warunków urzeczywistniania interesów prywatnych, reprezentując przy tym interesy całego społeczeństwa lub określonej wspólnoty, a także ze względu na uznawane powszechnie wartości

Oparcie funkcjonowania ustroju demokratycznego na suwerenności wolnych obywateli powoduje uznanie, że o jego rozwoju decyduje nie tylko sprawność instytucji, ale także postawy jednostek, za czym idą postulaty potrzeby angażowania się obywateli w sprawy ważne dla społeczności lokalnej, a więc ich udziału w procesie społecznej konkretyzacji dobra publicznego 5 . Partycypację obywatelską należy rozumieć jako proces, w trakcie którego obywatele uzyskują wpływ, a pośrednio i kontrolę nad decyzjami władz publicznych, gdy te decyzje mają bezpośredni lub pośredni wpływ na ich własne interesy. Uczestnictwo obywateli w życiu politycznym stanowi jedną z najważniejszych cech demokracji, a im wyższy stopień tego uczestnictwa wśród obywateli, tym silniejszy proces legitymizacji władzy, a co za tym idzie, podwyższenie stopnia demokratyczności systemu. Stąd też uznanie, że: „Demokracja wymaga aktywności obywateli, a ponieważ to przez dyskusję, powszechne zaangażowanie ludzi oraz zainteresowanie polityką cele społeczne powinny być definiowane i wprowadzane w życie. Bez zaangażowania obywateli $\mathrm{w}$ ten proces demokracja pozbawiona jest zarówno legitymizacji, jak i swej inspirującej siły"'. Tak więc z jednej strony poziom obywatelskiej aktywności i zaangażowania wpływa na realizowanie przez lokalny system polityczny jego konstytutywnych zadań, z drugiej zaś zachodzące w ramach tego systemu zmiany instytucjonalne, wprowadzane przez organy państwowe albo samorządowe, służące partycypacji, mogą przyczyniać się do wzrostu tego poziomu.

Samorząd terytorialny jest szczególną formą upodmiotowienia obywateli w procesie budowania społeczeństwa obywatelskiego ${ }^{7}$. Wymaga to określonego poziomu zaakceptowania przez mieszkańców istniejących struktur samorządowych i idącej

${ }^{4}$ Zob. A. Waśkiewicz, Dobro wspólne i społeczeństwo obywatelskie w teorii demokracji deliberatywnej i reprezentacji grupowej, [w:] Partycypacja obywatelska. Od teorii do praktyki spotecz$n e j$, red. A. Przybylski, A. Giza, Warszawa 2014.

5 A. Radiukiewicz, O obywatelskości we wspótczesnym świecie. Kierunki zmian i przestrzenie rozwoju, „Zoon Politikon” 2012, nr 3, s. 79.

${ }^{6}$ R.J. Dalton, Citizen Politics: Public Opinion and Political Parties in Advanced Industrial Democracy, New York 2002, s. 32.

7 Zob. B. Bartz, Realia i wyzwania w europejskim procesie rozwoju społeczeństwa cywilnego, [w:] Polski samorzad terytorialny w procesie integracji z Unia Europejska, red. B. Nawrot, J. Pokładecki, Poznań 2003, s. 16-20; S. Michałowski, Samorząd terytorialny a społeczeństwo obywatelskie, [w:] Samorząd terytorialny III Rzeczypospolitej. Dziesięć lat doświadczeń, red. S. Michałowski, Lublin 2002; B. Gąciarz, Instytucjonalizacja samorzadności. Aktorzy i efekty, Warszawa 2004, s. 65-78; J. Regulski, Samorzadność i społeczeństwo obywatelskie-kilka pytań i wiele wątpliwości, „Samorząd Terytorialny” 2013, nr 3. 
w ślad za tym partycypacji społecznej ${ }^{8}$. Idea obywatelskiej partycypacji ma się urzeczywistniać poprzez aktywność środowisk lokalnych w oparciu o liczny współudział członków wspólnoty samorządowej w zarządzaniu własnymi sprawami ${ }^{9}$. Należy jednak pamiętać, że członkowie wspólnoty samorządowej nie mają ustawowego obowiązku aktywnego udziału w życiu publicznym społeczności lokalnej, mają natomiast takie prawa.Członkostwo w samorządzie jest niezależne od osobistej aktywności czy też bierności w jego funkcjonowaniu, a więc całkowita bierność poszczególnych osób nie oznacza dla nich jakichkolwiek negatywnych konsekwencji ${ }^{10}$. Bierność ta w warunkach demokratycznych jest rzeczą normalną, aczkolwiek z punktu widzenia zasad demokracji niekorzystną. Jest ona konsekwencją koncentrowania się na sprawach prywatno-rodzinnych czy grupowo-towarzyskich, zaś jej przełamanie wymaga podjęcia działań edukacyjno-socjalizacyjnych lub silnego impulsu związanego z zagrożeniem uznawanych i cenionych wartości. Wskazać należy, że tak widziana bierność obywatelska może być i często jest w określonych warunkach traktowana jako przyzwolenie do podejmowania niezależnych działań władczych, co służy alienacji władzy lokalnej i umacnianiu się tendencji autorytarnych.

$\mathrm{Na}$ harmonijnym łączeniu demokracji pośredniej z wyraźnie szerszym niż dotychczas udziałem obywateli w podejmowaniu decyzji władczych oparty jest postulowany model zmian w administracji publicznej określany jako Dobre Rządzenie (Good Governance) ${ }^{11}$. Przyjmuje się w nim, że administracja publiczna jest formą współdziałania mającego na celu rozwiązywanie problemów społecznych. Stąd też podejmowanie decyzji i działań w jej obszarze powinno charakteryzować się: uczestnictwem obywateli w wypracowywaniu i podejmowaniu decyzji, sprawiedliwością sprzyjającą włączeniu i uwzględnieniu praw mniejszości, praworządnością, dążeniem do konsensusu zainteresowanych stron, transparentnością, elastycznością rozwiązań, skutecznością i wydajnością oraz szeroko pojmowaną odpowiedzialnością wobec społeczeństwa czy wspólnot lokalnych ${ }^{12}$. W rozważaniach

${ }^{8}$ Zob. K. Podemski, Uczestnictwo w życiu politycznym, [w:] Jednostka wobec wladzy, red. M. Ziółkowski, B. Pawłowski, R. Drozdowski, Poznań 1994, s. 103-116; B. Nawrot, Postawy i zachowania mieszkańców wobec samorzadu terytorialnego na poziomie matych miast i wsi, [w:] Władza lokalna a reforma samorządowa w Polsce, red. P. Dobrowolski, S. Wróbel, Katowice 1995, s. 56-68; M.S. Szczepański, Cnoty i instytucje obywatelskie w społeczności lokalnej, Tychy 2001; B. Nawrot, Miejsce ,inicjatyw niezależnych” na lokalnej scenie politycznej w Polsce, „Przegląd Politologiczny” 2009, nr 1, s. 39; S. Kozłowski, Upodmiotowienie społeczności lokalnych w okresie transformacji systemowej w Polsce, Warszawa 2015.

${ }^{9}$ M. Orłowska-Bednarz, Sołectwo jako przykład demokracji bezpośredniej, [w:] Stan i perspektywy demokracji bezpośredniej w Polsce, red. M. Marczewska-Rytko, Lublin 2000, s. 233.

${ }_{10}$ Zob. S. Kaźmierczak, Podmiot samorządu terytorialnego, [w:] Ustrój i funkcje samorządu terytorialnego. Studia i szkice, red. H. Rota, Wrocław 1993, s. 49-64; E. Olejniczak-Szałowska, Członkostwo wspólnoty samorządowej, „Samorząd Terytorialny” 1996, nr 5, s. 8-11.

${ }^{11}$ Koncepcja good governance - refleksje do dyskusji, Warszawa 2008.

${ }^{12}$ D. Długosz, J. Wygnański, Obywatele współdecydują. Przewodnik po partycypacji społecznej, Warszawa 2005, s. 12. 
teoretycznych odpowiednikiem tego modelu jest demokracja deliberatywna, której punktem wyjścia jest uznanie, że rządy ludu odbywają się nie tyle poprzez formalne mechanizmy, ale poprzez rzeczywisty dyskurs nad bieżącymi problemami społecznymi ${ }^{13}$.

Przynależna obywatelom demokratycznego państwa wolność do współdecydowania o swoich sprawach znajduje więc odzwierciedlenie w partycypacji będącej rodzajem praktyki społecznej ${ }^{14}$. Praktyka ta jest w rzeczywistości zmienna, ponieważ współpraca obywateli z przedstawicielami władz i administracji publicznej przyjmuje zmienne formy i zakresy, w ostateczności kształt tej współpracy zależy bowiem od charakteru, struktury i dynamiki relacji, jaka wiąże rządzących i rządzonych w danej wspólnocie politycznej. Wyzwaniem dla partycypacji obywatelskiej jest to, aby obie strony chciały z niej korzystać. Jednak podstawowe znaczenie ma postawa władzy publicznej (organów samorządu terytorialnego), bo to ona ma władzę i ona decyduje, czy i w jakim zakresie, z wyjątkiem sytuacji określonych prawnie, dopuszcza udział obywateli w kształtowaniu i realizacji swoich działań. Stosowanie różnych form partycypacji wymaga więc zmiany myślenia i podejścia do zarządzania publicznego, a także przekonania o korzyściach $\mathrm{z}$ niej wynikających ${ }^{15}$. Tak traktowana partycypacja obywatelska jest od lat promowana przez Unię Europejską, jak również inne międzynarodowe organizacje, rządy różnych krajów, a przede wszystkim przez organizacje pozarządowe.

Samo pojęcie partycypacji nie jest jednak jednoznaczne. Znajduje to wyraz w dodawaniu do tego terminu różnorakich określeń, takich jak: społeczna, publiczna, polityczna, obywatelska, indywidualna, wspólnotowa, horyzontalna, wertykalna. Przymiotniki te powinny określić konkretne obszary znaczeniowe partycypacji, jednak ich stosowanie nie jest treściowo tożsame, co wiąże się z wyraźną dowolnością stosowaną w określonych opracowaniach. Współcześnie przyjmuje się najczęściej za R. Langtonem, że interesująca nas postać partycypacji obejmuje cztery kategorie uczestnictwa obywateliw życiu wspólnot politycznych ${ }^{16}$ :

${ }_{13}$ Zob. J. Gastil, P. Levine, The Deliberation Democracy Handbook, San Francisco 2005; J. Sroka, Deliberacja i rzadzenie wielopasmowe. Teoria i praktyka, Wrocław 2008; A. Peisert, Demokracja deliberatywna: utopia czy ratunek dla demokratycznych wartości, „Kultura Liberalna” 2010, nr 2(52); B. Abramowicz, Koncepcja demokracji deliberatywnej jako odpowiedź na postulaty usprawnienia demokracji przedstawicielskiej, „Ruch Prawniczy, Ekonomiczny i Socjologiczny” 2011, z. 4.

${ }^{14}$ Zob. D.R. Kijowski, Partycypacja obywatelska w samorzadowych procesach decyzyjnych - zagadnienia ogólne, „Samorząd Terytorialny” 2010, nr 1-2; A. Olech, T. Kaźmierczak, Modele partycypacji publicznej, [w:] Partycypacja publiczna. O uczestnictwie obywateli w życiu wspólnoty lokalnej, red. A. Olech, Warszawa 2011, s. 100-111; W. Łukowski, Partycypacja, czyli o trudnościach w dzieleniu się władza, „Zoon Politikon” 2012, nr 3; A. Olech, Kiedy mieszkańcy uczestnicza w podejmowaniu decyzji, [w:] Przepis na uczestnictwo. Diagnoza partycypacji publicznej w Polsce, red. A. Olech, t. II, Warszawa 2013; A. Olech, P. Sobiesiak-Penszko, Partycypacja publiczna w Polsce. Diagnoza i rekomendacje, numer specjalny, „Analizy i Opinie” 2013, nr 3.

${ }_{15}$ T. Schimanek, Partycypacja obywatelska w społeczności lokalnej, Warszawa 2015, s. 10.

${ }^{16}$ R. Langton, What is citizen participation, [w:] Citizen Participation in America: Esseys on the State of the Art, ed. R. Langton, Lexington 1977. 
- partycypację obowiązkową,

- partycypację wyborczą,

- angażowanie obywateli,

- aktywność publiczną.

Partycypacja obowiązkowa to aktywność podejmowana indywidualnie przez obywateli w efekcie przymusu wynikającego z rozwiązań prawnych ${ }^{17}$. Chociaż jej realizacja stanowi m.in. podstawę finansową działań władz lokalnych (podatki, opłaty), to trudno doszukiwać się w niej bezpośrednich związków z lokalnym systemem politycznym, aczkolwiek po głębszej analizie wzajemne relacje na pewno można odkryć. W niektórych państwach demokratycznych partycypacja obowiązkowa obejmuje także przymus wyborczy ${ }^{18}$.

Podstawowe znaczenie dla lokalnego systemu politycznego ma partycypacja wyborcza, na którą składają się działania proceduralnie niezbędne do nominowania kandydatów i wybrania spośród nich reprezentantów do sprawowania funkcji decyzyjnych w organach władzy. Jest to więc forma świadomej i z zasady dobrowolnej aktywności obywateli niezbędnej do funkcjonowania demokracji przedstawicielskiej. Samorząd terytorialny w warstwie politycznej stanowi „głównie przestrzeń rywalizacji politycznej, toczonej pomiędzy różnymi podmiotami o uzyskanie takiej pozycji na lokalnej scenie politycznej, która zapewnia dostęp do lokalnych zasobów i wpływ na decyzje dotyczące ich wykorzystania"19. $\mathrm{Z}$ punktu widzenia partycypacji wyborczej na poziomie lokalnym podstawowym miernikiem aktywności obywatelskiej, a więc urzeczywistniania w minimalnym zakresie wymogów kultury politycznej uczestnictwa, jest frekwencja w wyborach do organów samorządu terytorialnego. W poszczególnych latach przedstawiało się to następująco: $1990-42,3 \% ; 1994-33,8 \%$; $1998-45,4 \% ; 2002-44,24 \%$; 2006-45,99\%; $2010-47,32 \% ; 2014-47,4 \%$.

Biorąc pod uwagę fakt, że znaczna część pozostającego w rejestrach elektoratu przebywa poza granicami kraju albo zamieszkuje bez zameldowania w innych miejscowościach, co utrudnia wpisanie ich na listy wyborców, można oceniać, że realna frekwencja wyborcza wynosi ok. 50\%. Niemniej oznacza to, że absencja wyborcza nadal kształtuje się też w granicach 50\%. Empiryczna weryfikacja hipotez wyjaśniających niski poziom frekwencji czy też wysoki poziom absencji w wyborach samorządowych stwarza w Polsce pewne problemy, albowiem w badaniach ankietowych prowadzonych krótko po wyborach zarówno w skali ogólnopolskiej, jak i na poziomie gmin liczba respondentów deklarujących uczestniczenie w nich z reguły przewyższa faktyczną frekwencję o 15 do 20 p.proc.

${ }_{17}$ T. Kaźmierczak, Partycypacja publiczna: pojęcie, ramy teoretyczne, [w:] Partycypacja publiczna..., s. 90 .

18 M. Cześnik, Partycypacja wyborcza w Polsce. Perspektywa porównawcza, Warszawa 2007, s. 24 i $79-81$.

19 A. Antoszewski, Samorzad jako pole rywalizacji politycznej, [w:] 20 lat samorzadu terytorialnego..., s. 47. 
Wyraźnym czynnikiem różnicującym poziom frekwencji w wyborach samorządowych okazuje się być podział regionalny. Przyczyn tego zróżnicowania można doszukiwać się $\mathrm{w}$ regionalnie ukształtowanych kulturach politycznego uczestnictwa, mających podłoże historyczne, co często w literaturze się czyni ${ }^{20}$. Biorąc pod uwagę średnią frekwencji w latach 2002-2014, ranking województw przedstawia się następująco (przy średniej krajowej - 46,29\%): Swiętokrzyskie 51,92\%; Podkarpackie - 49,98\%; Mazowieckie - 49,70\%; Lubelskie - 49,30\%; Małopolskie - 47,28\%; Podlaskie - 46,97\%. W tym okresie przeciętna frekwencja wyborcza przekroczyła średnią krajową również w województwie wielkopolskim (46,79\%) i warmińsko-mazurskim $(46,70 \%)$, przy czym w Wielkopolsce w 2010 i 2014 r. frekwencja ta była już, co prawda w niewielkim stopniu, niższa od osiągniętej w skali kraju. Zauważyć należy, że podejmowane zmiany prawne dotyczące reguł wyborczych, w których m.in. zakłada się, że przyczynią się one do wzrostu frekwencji wyborczej, przynoszą niewielki efekt, co widać np. w rozszerzeniu w 2014 r. wyborów większościowych w okręgach jednomandatowych na gminy liczące powyżej 20 tys. mieszkańców.

Istotnym korelatem uczestnictwa wyborczego w Polsce, także w wyborach lokalnych, pozostaje wiek. Osoby w średnim i starszym wieku zdecydowanie częściej wykazują aktywność wyborczą. Podobnie jest w przypadku innych typów wyborów, wyraźny wpływ bowiem na udział w wyborach samorządowych ma wykształcenie, status materialny oraz poziom religijności mierzony częstotliwością udziału w praktykach religijnych. Podkreślić należy, że w ostatnich latach czynnikiem różnicującym udział w wyborach samorządowych przestała być płeć. Kobiety stały się aktywniejsze i obecnie uczestniczą w wyborach w takim samym stopniu jak mężczyźni ${ }^{21}$.

Z licznych badań oraz obserwacji wyłania się obraz stabilności uczestnictwa wyborczego w Polsce. Te same osoby biorą udział powtarzalnie we wszystkich typach wyborów, traktując to jako rytualne wykonywanie obowiązku obywatelskiego; pewna grupa podejmuje aktywność wyborczą selektywnie, mobilizując się zgodnie z własnym uznaniem potrzeby podjęcia tego typu działań, np.w przypadku wyborów prezydenckich, parlamentarnych czy samorządowych; a jednocześnie znacząca ilościowo zbiorowość nie podejmuje żadnej aktywności wyborczej. W konsekwencji można postawić hipotezę o kształtowaniu się lokalnych, środowiskowych kultur politycznych absencji wyborczej czy raczej politycznego nieuczestniczenia, co może być efektem ułomnej socjalizacjii odzwierciedleniem

${ }^{20}$ M. Cześnik, Partycypacja wyborcza..., s. 44.

${ }^{21}$ Zob. ibidem, s. 43-44 i 126-167; M. Żerkowska-Balas, A. Kozaczuk, Obywatele i wybory, Warszawa 2013; M. Cześnik, Uczestnictwo wyborcze a podaż w polskim systemie politycznym - komentarz do badań, [w:] Obywatele i wybory, red. D. Sześciło, M. Cześnik, R. Markowski, Warszawa 2013; M. Żerkowska-Balas, M. Zaremba, Partycypacja nowych wyborców, Warszawa 2015, www. batory.org.pl (dostęp 15.11.2016). 
słabości polskiego systemu politycznego. Weryfikacja tej hipotezy wymaga jednak pogłębionych badań empirycznych o charakterze jakościowym.

W przypadku Polski do partycypacji wyborczej na poziomie lokalnym powinno się zaliczać także referenda w sprawie odwołania organów samorządu terytorialnego (pozostałe referenda, w zależności od tego, kto jest ich inicjatorem, należy sytuować w sferze aktywności publicznej lub angażowania obywateli). Stosunkowo niski poziom angażowania się mieszkańców w działania wyborcze pozostaje w silnym związku, oczywiście obok uwarunkowań wynikających ze specyfiki lokalnych układów politycznych, z ograniczoną skutecznością tych referendów lokalnych, pomimo dokonania w 2006 r. zmian prawnych w tym zakresie. W latach 1992-2010 przeprowadzono 547 tzw. referendów odwoławczych, spośród których tylko 65 (a więc 11,9\%) było prawomocnych. W kadencji 2010-2014 odbyło się 117 referendów, w tym 39 miało tzw. charakter podwójny, dotyczyło bowiem odwołania zarówno organu wykonawczego gminy, jak i organu stanowiącego, przedmiotem 1 było tylko odwołanie rady gminy, a 2 - odwołanie rady powiatu. Spośród nich tylko 16 (13,7\%) okazało się prawomocnych. Wskazać jednak należy, że odwołano w ten sposób Prezydenta i Radę Miasta Bytomia (frekwencja 21,8\%), Prezydenta i Radę Miasta Elbląga (24,6\%), co wyraźnie świadczy o tym, iż przyjęte limity niezbędnego dla prawomocności referendów uczestnictwa da się osiągnąć przy w miarę sprawnych działaniach mobilizacyjnych. W okresie od listopada 2015 r. do września 2016 r. przeprowadzono już 25 referendów odwoławczych, z tego tylko 3 były prawomocne ${ }^{22}$.

O zakresie partycypacji w lokalnej demokracji przedstawicielskiej może też świadczyć frekwencja w wyborach do jednostek pomocniczych gmin, a zatem do organów pozostających najbliżej mieszkańców, które co prawda nie mają zbyt wielkich uprawnień i nie dysponują większymi funduszami, ale wydają się najbardziej kompetentne w sprawach danego miejsca. W większych miastach średnia frekwencja jest wszędzie niska i utrzymuje się na takim poziomie mimo wzrostu środków finansowych pozostających do dyspozycji jednostek pomocniczych. Przykładowo: w 2015 r. frekwencja w wyborach do rad osiedli wynosiła: w Poznaniu - 7,74\%, Lublinie - 6,11\%, Opolu - 7,4\%, Szczecinie - 7,88\%, Gdyni - 8,96\%, Gdańsku - nieco ponad $11 \%$, i nie różniła się wyraźnie od frekwencji

${ }^{22}$ Zob. B. Węglarz, Referenda lokalne w sprawie odwołania organów jednostek samorzadu terytorialnego $w$ czwartej kadencji (lata 2002-2006), „Samorząd Terytorialny” 2007, nr 7-8; M. Rachwał, Referenda w sprawie odwołania organu gminy przed uptywem kadencji - doświadczenia lat 2006-2010, [w:] Wieloaspektowość samorzadności gminnej w Polsce, red. B. Nawrot, J. Pokładecki, Poznań 2011; Raport Kancelarii Prezydenta RP nt. referendów lokalnych, www.prezydent.pl (dostęp 21.12.2016); M. Rachwał, Referenda w sprawie odwołania organu samorzadu terytorialnego - doświadczenia lat 2010-2014, „Kwartalnik Naukowy OAP UW ePolitikon” 2014, $\mathrm{nr}$ 11; J. Kowalik, Referendum odwoławcze w gminie - instytucja wyborców czy wybieranych?, „Preferencje Polityczne: Postawy. Identyfikacje. Zachowania” 2014, nr 8; M. Rulka, Próg frekwencyjny w gminnych referendach odwoławczych, „Infos” 2016, nr 17. 
w poprzednich wyborach. Tradycyjnie niska, aczkolwiek zróżnicowana, pozostaje frekwencja w wyborach sołtysów, a tym bardziej na zebraniach wiejskich ${ }^{23}$.

Angażowanie obywateli jako forma partycypacji obywatelskiej to działania inicjowane i kontrolowane przez władze publiczne w toku realizacji ich statutowych zadań. Ich celem może być prosta, zinstrumentalizowana mobilizacja obywateli do wykonywania określonych zadań albo też, mające wymiar aksjologiczny, doskonalenie procesu decyzyjnego i jakości usług publicznych w ten sposób, by zapewnić możliwy konsensus, a co za tym idzie - wsparcie i przychylność obywateli ${ }^{24}$. To drugie wymaga jednak szczególnej woli ośrodków decyzyjnych, a więc władz samorządowych.

W polskich warunkach władze samorządowe, a nade wszystko władze gmin, włączają mieszkańców w życie publiczne, wykorzystując przede wszystkim najmniej wymagające mechanizmy, tj. informowanie i ewentualne wyjaśnianie podjętych decyzji oraz ichkonsultowanie ${ }^{25}$. Dostęp do informacji to wymóg minimalny do skorzystania z obywatelskiej wolności do współdecydowania. Mimo coraz większego znaczenia, jakiego we wszelkiej komunikacji nabierają nowoczesne technologie, partycypacja publiczna mieszkańców o charakterze informacyjnym nadal ma przede wszystkim tradycyjny charakter ${ }^{26}$. Najczęściej odbywa się w wyniku bezpośredniego kontaktu mieszkańca z urzędem, czytania przez niego ogłoszeń na tablicach informacyjnych, ewentualnego korzystania z prasy lokalnej, która często przybiera postać bezpłatnych biuletynów redagowanych przez urzędników i wychwalających osiągnięcia władz oraz udziału w zebraniach z przedstawicielami władz lokalnych. Stosunkowo rzadko natomiast korzysta się z nowoczesnych technologii, w tym Internetu, a jeśli już do komunikacji z władzami publicznymi przez Internet dochodzi, ma ona przede wszystkim charakter bierny $^{27}$. W tym przypadku informacje „o sprawach publicznych” są udostępniane głównie w „Biuletynach Informacji Publicznej” (BIP).

Mieszkańcy mogą też być obecni na posiedzeniach samorządowych organów stanowiących albo ich komisji, co właśnie spełnia głównie funkcje informacyjne, albowiem dopuszczenie ich do głosu w trakcie np. rady gminy nie jest regulowane ustawowo i tym samym wymaga wyraźnego tego określenia w statucie tejże rady, co raczej rzadko się zdarza ${ }^{28}$.

${ }^{23}$ K. Łabędź, Partycypacja obywatelska na poziomie lokalnym - formy i ograniczenia, „Przegląd Politologiczny" 2015, nr 4, s. 96.

24 J.L. Creighton, The Public Participation Handbook, San Francisco 2005, s. 9.

25 A. Olech, P. Sobiesiak-Penszko, Partycypacja publiczna..., s. 5-8.

${ }^{26}$ K. Kentnowska, Prawo do informacji w społeczeństwie informacyjnym z uwzględnieniem środków elektronicznych, [w:] Partycypacja spoleczna w samorzadzie terytorialnym, red. B. Dolnicki, Warszawa 2014, s. 703-800.

${ }^{27}$ A. Olech, P. Sobiesiak-Penszko, Partycypacja publiczna..., s. 15.

${ }^{28}$ S. Gajewski, A. Jakubowski, Prawne problemy udziału mieszkańców w sesjach rady gminy i posiedzeniach jej komisji, [w:] Partycypacja społeczna..., s. 147-162. 
Zdecydowanie najpowszechniejszym sposobem aktywnego włączania mieszkańców w lokalne życie publiczne, a więc w proces podejmowania decyzji, są konsultacje społeczne ${ }^{29}$. Regulacje dotyczące konsultacji społecznych można znaleźć w wielu aktach prawnych. Na mocy samorządowych ustaw ustrojowych organy samorządowe zobowiązane są, w wypadkach przewidzianych ustawą, do prowadzenia na swoim terytorium konsultacji z mieszkańcami oraz mogą je prowadzić fakultatywnie w innych sprawach ważnych dla danej jednostki samorządowej. Pod konsultacje władze samorządowe najczęściej poddają następujące kwestie: plan zagospodarowania przestrzennego, strategię rozwoju, inwestycje z zakresu infrastruktury drogowej, zmianę granic oraz inwestycje dotowane z funduszy europejskich ${ }^{30}$.

Obraz konsultacji społecznych na polskiej scenie lokalnej nie napawa optymizmem i budzi wiele kontrowersji. Niektóre z nich wynikają z niedookreślenia, w jakich kwestiach konsultacje powinny mieć miejsce, ich uznaniowego oraz niewiążącego charakteru. Inne ze stosunku władz samorządowych, które często przejawiają postawę „,właściciela gminy”, a konsultacje traktują niezbyt poważnie lub instrumentalnie. Konsultacje prowadzone są najczęściej, gdy wymaga tego prawo, a i wtedy mają często fasadowy charakter, obywatelom często bowiem daje się do opiniowania gotowe dokumenty, których nie rozumieją, często nie odbywają się żadne spotkania konsultacyjne ${ }^{31}$. Rzadko też wyniki konsultacji są wykorzystywane przy podejmowaniu decyzji. Dominują pasywne formy zasięgania opinii: osobiste zastrzeżenia zgłaszane w urzędzie gminy w określonych terminach czy ankiety (najczęściej prasowe) ${ }^{32}$.

Pozytywnym zjawiskiem w tym zakresie jest coraz szersze stosowanie (głównie w dużych miastach) fakultatywnych konsultacji społecznych realizowanych on-line. Obok tego korzysta się z wysłuchań publicznych, badań fokusowych i form pararefendalnych. Eksperymentalnie wprowadza się też instrumenty deliberacyjne (sondaże deliberacyjne, sądy obywatelskie, panele obywatelskie), a także jest wykorzystywana profesjonalna pomoc w przeprowadzaniu konsulta-

29 Zob. G. Makowski, Przeglad prawno-instytucjonalnych ram konsultacji społecznych na poziomie samorzadu terytorialnego, [w:] Prawo a partycypacja publiczna. Bilans monitoringu 2012, red. P. Sobiesiak-Penszko, Warszawa 2013; T. Mollo, Konsultacje komunalne jako klasyczna forma partycypacji społecznej, [w:] Partycypacja społeczna..., s. 244-258; M. Sidor, Konsultacje spoteczne $w$ największych polskich miastach: prawne aspekty - praktyczne zastosowanie, [w:] ibidem, s. 891-906; D. Sześciło, Konsultacje społeczne w gminie w świetle orzecznictwa sadów administracyjnych, „Samorząd Terytorialny” 2014, nr 1-2.

${ }^{30}$ B. Węglarz, Ewolucja lokalnej demokracji przedstawicielskiej w Polsce po 1989 roku, Kraków 2013, s. 128 i 139.

${ }^{31}$ Aktorzy i dylematy partycypacji - jak dbać o jakość procesów i lepsze uczestnictwo?, „Animacja Życia Publicznego" 2013, nr 3, s. 38-41, www.civitas.edu.pl (dostęp 20.12.2016).

32 Zob. Raport końcowy z badania efektywności mechanizmów konsultacji spolecznych, 43/DPP/PN/2009, Ministerstwo Pracy i Polityki Społecznej oraz Millward Brown SMG/KRC, Warszawa 2011; M. Arczewska, Wspótpraca międzysektorowa przy tworzeniu polityk publicznych dotyczacych spraw spotecznych i ochrony środowiska, Warszawa 2011. 
cji $^{33}$. W czołówce dużych miast stosujących te eksperymenty znajduje się Poznań. W środowiskach promujących partycypację obywatelską proponuje się zwiększenie zakresu konsultacji obligatoryjnych poprzez uchwalenie prawnego obowiązku konsultacji budżetu gminy, co raczej ma nikłe szanse realizacji.

Szczególną formą konsultacji społecznych w gminach jest budżet obywatelski. W ramach tej instytucji mieszkańcom pozostawia się decyzję, jak ma być wydatkowana określona pula (niewielka w skali całego budżetu) środków publicznych w ich mieście czy gminie. Instrument ten nie ma bezpośredniego umocowania ustawowego - funkcjonuje jako forma konsultacji społecznych z mieszkańcami ${ }^{34}$. Zastosowano go po raz pierwszy 5 lat temu w Sopocie. Obecnie realizuje go ok. 160 gmin (głównie miejskich). Zasady zgłaszania projektów i opowiadania się przez mieszkańców za tymi, które ich zdaniem powinny zostać sfinansowane z puli budżetu obywatelskiego, są zróżnicowane, ponieważ ustalają je poszczególne rady gmin. W zdecydowanej większości budżety obywatelskie mają charakter konkursu (wygrywa projekt uzyskujący najwięcej głosów), a nie służą deliberacji prowadzącej do ustalenia najlepszych rozwiązań. Głosowanie odbywa się w sposób zindywidualizowany, najczęściej w systemie on-line, co niekoniecznie odzwierciedla zbiorowe preferencje. Stąd postulaty, by prawnie określić podstawowe, ogólne reguły funkcjonowania tych budżetów, w tym wynikająca z pięcioletnich doświadczeń Sopotu propozycja zastąpienia takiego głosowania panelem obywatelskim ${ }^{35}$.

Pamiętać też należy o tym, że istotny wpływ na kształt, i tak mało znaczącego w wydatkach gmin, budżetu obywatelskiego ma administracja samorządowa dokonująca selekcji zgłoszonych projektów i oszacowania nakładów na ich realizację. Przykładem błędów popełnionych w tym zakresie może być tzw. Centrum Sportów Wrotkarskich w Poznaniu ${ }^{36}$. Można więc stwierdzić, że budżety obywatelskie będące jedną z form partycypacji nie spełniają, przynajmniej dotychczas, swojej roli37.

${ }^{33}$ Zob. T. Kaźmierczak, Partycypacja publiczna: pojęcie..., s. 97-90; A. Olech, T. Kaźmierczak, Modele partycypacji..., s. 106-111; M. Kwiatkowska, Sady obywatelskie jako przykład demokracji partycypacyjnej, „Samorząd Terytorialny” 2013, nr 6; B. Dolnicki, Partycypacja spoteczna w samorzadzie terytorialnym, Warszawa 2014.

${ }^{34}$ Zob. W. Kębłowski, Budżet partycypacyjny. Krótka instrukcja obstugi, Warszawa 2013; M. Małecka-Łyszczek, Partycypacja w ramach public governance, [w:] Partycypacja społeczna..., s. $52-53$.

${ }^{35}$ Zob. K. Bandarzewski, Ekspertyza dotyczaca aktualnych podstaw prawnych i zmian niezbędnych dla rozwoju budżetów partycypacyjnych na poziomie lokalnym w Polsce, Warszawa 2013, www.maszglos.pl (dostęp 15.11.2016); D. Kraszewski, K. Mojkowski, Budżet obywatelski w Polsce, Warszawa 2014; D. Sześciło, Koncepcje ustawowego uregulowania budżetów obywatelskich (partycypacyjnych), Warszawa 2014, www.masz głos.pl (dostęp 14.11.2016).

36 „Gazeta Wyborcza. Poznań”, 14.11.2016.

${ }^{37}$ K. Łabędź, Partycypacja obywatelska..., s. 99-100. 
Partycypacja publiczna ujmowana jako aktywność publiczna polega na działaniach inicjowanych przez obywateli oraz przez nich kontrolowanych, których celem jest wpływanie na decyzje podejmowane przez władze publiczne i podporządkowane im jednostki organizacyjne. Jest to najczęściej aktywność zorganizowana, realizowana przez szerokie, pluralistyczne oddziaływanie organizacji pozarządowych różnego typu lub powstające ad hoc inicjatywy społeczne. Przedmiotem obywatelskich oddziaływań mogą być zarówno procesy ustawodawcze i uchwałodawcze, jak i procesy wykonawcze (kształtowanie i realizowanie polityk publicznych). Wśród form takiej aktywności wskazać można m.in. lobbowanie, protest, nieposłuszeństwo obywatelskie, edukacja obywatelska, rzecznictwo interesów, kontrola obywatelska itp. Istotne znaczenie w tym obszarze ma prawne uregulowanie procedur składania petycji ${ }^{38}$. Skuteczność takich oddziaływań zależy od zdolności do zorganizowania się, pozyskiwania informacji i środków, doboru właściwych strategii i taktyki działania i nabywania odpowiednich kompetencji ${ }^{39}$. W ostatnich latach szczególną uwagę należy zwrócić na różnorodne formy działania tzw. ruchów miejskich ${ }^{40}$.

Szczególnymi postaciami aktywności publicznej, często jednak łączącej się $\mathrm{z}$ angażowaniem publicznym, są: referenda przedmiotowe (merytoryczne), inicjatywy uchwałodawcze i inicjatywy lokalne. Jak wynika z praktyki, referenda przedmiotowe (dla ważności których frekwencja musi przekroczyć 30\%) mają większą szansę uzyskać prawomocność niż referenda odwoławcze, aczkolwiek ich liczba jest dużo mniejsza niż tych drugich. W kadencji 2006-2010 przeprowadzono 50 referendów merytorycznych, w tym 28 było ważnych (56\%); w latach 2010-2013 było ich 22, w tym 9 ważnych (41\%) (Raport Kancelarii..., 2013, s. 5). Inicjatywa przeprowadzenia referendów przedmiotowych najczęściej wychodzi od mieszkańców (a raczej tworzonych ad hoc grup inicjatywy społecznej), czasem wbrew stanowisku organów samorządowych, przy czym do kwestii spornych należy zaliczyć głównie lokalizację inwestycji postrzeganych przez mieszkańców w kategoriach zagrożenia (np. kopalnie odkrywkowe, elektrownie wiatrowe, elektrownie atomowe, spalarnie np. śmieci itp. ${ }^{41}$ czy też organizacji

${ }^{38}$ K. Izdebski, Ustawa o petycjach. Fundament czy fasada?, Warszawa 2015, www.batory. org.pl (dostęp 15.11.2016).

${ }^{39}$ K. Łabędź, Partycypacja obywatelska..., s. 100-101.

40 Zob. S. Wróbel, Powstanie i ewolucja miejskich ruchów politycznych. Przypadek miast górnośląskich, „Przegląd Politologiczny” 2005, nr 1; idem, Miejskie ruchy polityczne. Wybrane zagadnienia, [w:] Od teorii do praktyki politycznej, red. M. Kołodziejczak, R. Rosicki, Poznań 2012; M. Kokoszkiewicz, Ruchów miejskich życie wewnętrzne, „Animacja Życia Publicznego” 2013, nr 3, www.civitas.edu.pl (dostęp 15.11.2016); P. Kubicki, Ruchy miejskie w Polsce. Próba analizy, www. slideshare.net (dostęp 15.11.2016); L. Megler, Z liderami czy bez liderów? Partycypacja na przyktadzie nowych ruchów miejskich, „Animacja Życia Publicznego” 2013, nr 3.

${ }^{41}$ Raport Kancelarii Prezydenta RP nt. referendów lokalnych, www.prezydent.pl (dostęp 21.12.2016), s. 35; K. Łabędź, Partycypacja obywatelska..., s. 98-99. 
zbyt kosztownych imprez (czego przykładem jest Kraków, gdzie w referendum dotyczącym organizacji olimpiady zimowej i ją odrzucającym frekwencja wyniosła ok. 36\%). W tych sytuacjach o przekroczeniu wymagalnego progu frekwencji decyduje wyraźny opór mieszkańców wobec planów władz. W niektórych przypadkach jednak decyzje ważnych referendów mają postać pozytywną, np. referendum z 2014 r. w sprawie przyłączenia gminy wiejskiej Zielona Góra do Miasta Zielona Góra (frekwencja 55,2\%).

Inną formą wpływania na działania organów samorządu jest prawo do inicjatywy uchwałodawczej, a więc wprowadzania przez mieszkańców pod obrady rady istotnej dla nich sprawy wraz z proponowanym rozwiązaniem, o ile statut gminy to przewiduje. W takim przypadku rada musi ją rozpatrzyć i zająć stanowisko. Rady gmin nie mają obowiązku ustalania regulacji dotyczących zastosowania tego prawa, tym bardziej że pojawiły się w tym względzie kontrowersje prawne. Można szacować, iż sto kilkadziesiąt gmin wprowadziło do swoich statutów odpowiednie regulacje, w których jednak niekiedy bardzo wysoko określono próg umożliwiający złożenie takiej inicjatywy. Jej wykorzystanie jest w dalszym ciągu nikłe, czego powodem jest brak upowszechnienia informacji o tych uprawnieniach ${ }^{42}$.

Nowelizacją 22 stycznia 2010 r. ustawy o działalności pożytku publicznego i wolontariacie (Dz.U. 2010, nr 28, poz. 146) wprowadzono do polskiego porządku prawnego instytucję inicjatywy lokalnej, która stanowić miała nową formę współpracy służącą pobudzeniu działań obywateli w celu wspólnego rozwiązywania ważnych spraw społeczności lokalnych. Mogą oni bezpośrednio, albo za pośrednictwem organizacji pozarządowych, złożyć do swojego samorządu terytorialnego wniosek o realizację zadania publicznego, w którego przygotowanie lub przeprowadzenie są skłonni się zaangażować (szczególnie przez wkład pracy społecznej). Zadania realizowane w ramach inicjatywy mogą dotyczyć m.in. lokalnej infrastruktury, działalności charytatywnej, sportowej, kulturalnej, edukacyjnej czy dotyczącej bezpieczeństwa publicznego. Składanie wniosków o inicjatywę lokalną jest prawem mieszkańców. Nieprzyjęcie stosownej uchwały przez samorząd gminny, powiatowy czy wojewódzki de facto pozbawia mieszkańców możliwości realizacji ich pomysłów, a bezczynność samorządu może się nawet spotkać z zarzutem naruszenia prawa. Jak wynika z danych Ministerstwa Pracy i Polityki Społecznej, w 2010 r. zaledwie 128 samorządów gminnych $(5,1 \%)$ współpracowało z mieszkańcami lub ich organizacjami na podstawie przepisów dotyczących inicjatywy lokalnej. W 2011 r. były to 122 samorządy (4,7\%), w 2012 r. 73 (2,9\%), w 2013 r. 126 (5\%), a w 2014 r. 160 (6,4\%) samorządów współpracowało z miesz-

${ }^{42}$ Zob. A. Miruć, Obywatelska inicjatywa uchwałodawcza, „Samorząd Terytorialny” 2010, nr 1-2; A.K. Piasecki, Inicjatywa obywatelska w praktyce politycznej III RP, „Państwo i Społeczeństwo" 2010, nr 2; Kiepsko z inicjatywa ustawodawcza w gminach, www.portalsamorządowy. pl (dostęp 15.11.2016); H. Izdebski, Podstawy prawne wprowadzenia instytucji inicjatywy uchwałodawczej mieszkańców do statutów jednostek samorzadu terytorialnego, Warszawa 2013, www. maszgłos.pl (dostęp 15.11.2016); Wyrok NSA z 21 listopada 2013 r., sygn. II OSK 1887/13. 
kańcami w ramach inicjatywy lokalnej. Trzeba więc przyznać, że mimo wielu korzyści inicjatywa lokalna jest wykorzystywana stosunkowo rzadko ${ }^{43}$.

Istnienie różnego rodzaju ciał doradczo-konsultacyjnych przy organach władzy samorządowej sprzyja urzeczywistnianiu partycypacji zarówno w aspekcie angażowania obywateli, jak ich własnej aktywności publicznej. Działania takie stanowią formę harmonizacji interesów. Kolektywność w tym przypadku nie oznacza tylko uzgodnienia stanowiska, ale także jest istotną formą rozwiązywania konfliktów decyzyjnych. Przy korzystaniu z pomocy organów opiniodawczo-doradczych występuje zwiększona szansa na zachowanie wszystkich elementów procesu podejmowania decyzji ${ }^{44}$. Szereg tych ciał posiada uregulowanie prawne, niektóre $\mathrm{z}$ nich muszą być powołane obligatoryjnie, większość jednak może być tworzona fakultatywnie według woli organów samorządowych.

Spełnianie przez polskie struktury samorządu terytorialnego standardów europejskich w sensie ustrojowo-prawnym nie oznacza, że standardy te znajdują swój wyraz w społecznym zaangażowaniu w procesie urzeczywistniania przez te struktury ich celów. Dość powszechnie w literaturze przedmiotu przyjmuje się, że w porównaniu z innymi państwami Europy Środkowo-Wschodniej, nie mówiąc o państwach Europy Zachodniej, tzw. kapitał społeczny sytuuje się w Polsce na niskim poziomie. Uznaje się też, że zaangażowanie społeczne jest dużo niższe niż obywateli innych państw postkomunistycznych ${ }^{45}$.

Wbrew oczekiwaniom, że wraz z konsolidacją systemu demokratycznego następować będzie rozwój społeczeństwa obywatelskiego, od pewnego czasu najczęściej przyjmowane wskaźniki pokazują, iż proces taki nie postępuje. W tym kontekście szczególny niepokój budzą ataki związanych z obecnym rządem mediów na organizacje promujące i wspierające partycypację obywatelską.

$\mathrm{Z}$ polskiej praktyki funkcjonowania lokalnego systemu politycznego wynika, iż choć w znacznej części organizacje pozarządowe starają się wyjść ze strefy klientyzmu w relacjach z władzami samorządowymi, podkreślając swoją podmiotowość i niezależność, to jednak fałszywie pojmowane przywództwo w elitach samorządowych skutkuje niechęcią i nieumiejętnością korzystania z potencjału partnerów obywatelskich ${ }^{46}$.

${ }^{43}$ K. Mojkowski, Pięć lat inicjatywy lokalnej. Porównanie przepisów dotyczacych inicjatywy lokalnej z praktyka ich stosowania w latach 2010-2014, www.masz głos.pl (dostęp 20.12.2016).

${ }_{44}$ T. Schimanek, Partycypacja obywatelska..., s. 12.

${ }^{45}$ Zob. P. Sztompka, Zaufanie. Fundament społeczeństwa, Kraków 2007; Zmiany w psychologicznych profilach elektoratów partyjnych, 19/2011, Komunikat z badań CBOS, Warszawa 2011; Aktywność społeczna $w$ organizacjach obywatelskich, BS/18/2012, Komunikat z badań CBOS, Warszawa 2012; M. Grabowski, Społeczeństwo obywatelskie w Polsce A.D. 2012, Komunikat z badań CBOS, Warszawa 2012, s. 28-30; J. Czapiński, Kapitat społeczny, [w:] Diagnoza społeczna 2013, red. J. Czapiński i T. Panek, Warszawa 2013, s. 286-287; Zaufanie w stosunkach międzyludzkich, 29/2014, Komunikat z badań CBOS, Warszawa 2014; K. Łabędź, Partycypacja obywatelska..., s. 100-104.

${ }^{46}$ Zob. P. Kubicki, Ruchy miejskie...; T. Schimanek, Partycypacja obywatelska ..., s. 12. 
Nie da się ukryć, że w polskich samorządach dominuje nadal tradycyjny model zarządzania publicznego, który polega na egzekwowaniu przez organy władzy i administracji uprawnień władczych. Decyzje dotyczące kwestii publicznych podejmowane są „odgórnie” i „odgórnie” wprowadzane w życie przez właściwe instytucje. Stosowane formy partycypacyjne przyjmują więc często postać „wymuszanych" prawnie lub też okazjonalnych eksperymentów. Najczęściej dopiero wtedy, gdy ujawniają się konflikty o istniejące czy potencjalne zasoby, dochodzi do prób wywierania nacisku na działania władzy publicznej. Tym samym partycypacja ujawnia się raczej jako skutek konfliktów o zasoby, które tym bardziej mogą się nasilać, im tych zasobów będzie mniej. Przyjęte dotychczas w Polsce rozwiązania prawne stwarzają znaczne możliwości partycypacji obywatelskiej na poziomie lokalnym. Pomimo to znaczna część społeczeństwa pozostaje nadal bierna, co wskazuje, że poczyniona w Polsce decentralizacja pozostaje wciąż na poziomie administracyjnym, a nie społecznym. Procesy partycypacyjne wymagają kultury współuczestnictwa, czyli szerokiego otwarcia władzy na obywateli, a co za tym idzie, wymagają od władz samorządowych zmiany kultury zarządzania na taką, w której dominującymi wartościami są: równość, deliberacja, konsensus oraz interes ogółu. Te dosyć abstrakcyjne wartości przekładają się na partycypację publiczną, czyli proces, w którym interesariusze, grupy obywateli, organizacje pozarządowe i administracja publiczna są zaangażowani razem w tworzenie polityki publicznej, zanim zapadnie decyzja polityczna.

\section{Bibliografia}

Abramowicz B., Koncepcja demokracji deliberatywnej jako odpowiedź na postulaty usprawnienia demokracji przedstawicielskiej, „Ruch Prawniczy, Ekonomiczny i Socjologiczny" 2011, z. 4.

Aktorzy i dylematy partycypacji - jak dbać o jakość procesów i lepsze uczestnictwo?, „Animacja Życia Publicznego" 2013, nr 3, www.civitas.edu.pl (dostęp 20.12.2016).

Aktywność społeczna $w$ organizacjach obywatelskich, BS/18/2012, Komunikat z badań CBOS, Warszawa 2012.

Antoszewski A., Istota władzy samorządowej, [w:] Polityka lokalna. Właściwości determinanty, podmioty, red. E. Ganowicz, L. Rubisz, Torun 2008.

Antoszewski A., Samorzad jako pole rywalizacji politycznej, [w:] 20 lat samorzadu terytorialnego w Polsce. Sukcesy, porażki, perspektywy, red. K. Mieczkowska-Czerniak, K. Radzik-Maruszak, Lublin 2012.

Arczewska M., Wspótpraca międzysektorowa przy tworzeniu polityk publicznych dotyczqcych spraw społecznych i ochrony środowiska, Warszawa 2011.

Bandarzewski K., Ekspertyza dotyczaca aktualnych podstaw prawnych i zmian niezbędnych dla rozwoju budzetów partycypacyjnych na poziomie lokalnym w Polsce, Warszawa 2013, www.maszglos.pl (dostęp 15.11.2016). 
Bartz B., Realia $i$ wyzwania $w$ europejskim procesie rozwoju społeczeństwa cywilnego, [w:] Polski samorzad terytorialny w procesie integracji z Unia Europejska, red. B. Nawrot, J. Pokładecki, Poznań 2003.

Creighton L., The Public Participation Handbook, San Francisco 2005.

Czapiński J., Kapitał społeczny, [w:] Diagnoza społeczna 2013, red. J. Czapiński i T. Panek, Warszawa 2013.

Cześnik M., Partycypacja wyborcza w Polsce. Perspektywa porównawcza, Warszawa 2007.

Cześnik M., Uczestnictwo wyborcze a podaż w polskim systemie politycznym - komentarz do badań, [w:] Obywatele i wybory, red. D. Sześciło, M. Cześnik, R. Markowski, Warszawa 2013.

Dalton R.J., Citizen Politics: Public Opinion and Political Parties in Advanced Industrial Democracy, New York 2002.

Dolnicki B., Partycypacja społeczna w samorzadzie terytorialnym, Warszawa 2014.

Długosz D., Wygnański J., Obywatele współdecydują. Przewodnik po partycypacji spotecznej, Warszawa 2005.

Gajewski S., Jakubowski A., Prawne problemy udziału mieszkańców w sesjach rady gminy i posiedzeniach jej komisji, [w:] Partycypacja społeczna $w$ samorzadzie terytorialnym, red. B. Dolnicki, Warszawa 2014.

Gastil J., Levine P., The Deliberation Democracy Handbook, San Francisco 2005.

Gąciarz B., Instytucjonalizacja samorządności. Aktorzy i efekty, Warszawa 2004.

Grabowski M., Spoleczeństwo obywatelskie w Polsce A.D. 2012, Komunikat z badań CBOS, Warszawa 2012.

Hryniewicz J.T., Analiza funkcjonowania samorzadu lokalnego w oparciu o kluczowe kategorie nauk o zarzadzaniu: misje, cele, własność, kontekst organizacyjny i efektywność, [w:] 20 lat samorzadu terytorialnego w Polsce. Sukcesy, porażki, perspektywy, red. K. Mieczkowska-Czerniak, K. Radzik-Maruszak, Lublin 2012.

Izdebski H., Podstawy prawne wprowadzenia instytucji inicjatywy uchwałodawczej mieszkańców do statutów jednostek samorządu terytorialnego, Warszawa 2013, www.maszgłos.pl (dostęp 15.11.2016).

Izdebski K., Ustawa o petycjach. Fundament czy fasada?, Warszawa 2015, www.batory. org.p(dostęp 15.11.2016).

Kaźmierczak S., Podmiot samorządu terytorialnego, [w:] Ustrój i funkcje samorządu terytorialnego. Studia i szkice, red. H. Rota, Wrocław 1993.

Kaźmierczak T., Partycypacja publiczna: pojęcie, ramy teoretyczne, [w:] Partycypacja publiczna. O uczestnictwie obywateli w życiu wspólnoty lokalnej, red. A. Olech, Warszawa 2011.

Kentnowska K., Prawo do informacji w społeczeństwie informacyjnym z uwzględnieniem środków elektronicznych, [w:] Partycypacja społeczna w samorządzie terytorialnym, red. B. Dolnicki, Warszawa 2014.

Kębłowski W., Budżet partycypacyjny. Krótka instrukcja obstugi, Warszawa 2013.

Kiepsko z inicjatywa ustawodawcza w gminach, www.portalsamorządowy.pl (dostęp 15.11.2016).

Kijowski D.R., Partycypacja obywatelska w samorzadowych procesach decyzyjnych - zagadnienia ogólne, „Samorząd Terytorialny” 2010, nr 1-2. 
Kokoszkiewicz M., Ruchów miejskich życie wewnętrzne, „Animacja Życia Publicznego” 2013, nr 3, www.civitas.edu.pl (dostęp 15.11.2016).

Koncepcja good governance - refleksje do dyskusji, Warszawa 2008.

Kowalik J., Referendum odwoławcze w gminie - instytucja wyborców czy wybieranych?, „Preferencje Polityczne: Postawy. Identyfikacje. Zachowania” 2014, nr 8.

Kozłowski S., Upodmiotowienie społeczności lokalnych $w$ okresie transformacji systemowej $w$ Polsce, Warszawa 2015.

Kraszewski D., Mojkowski K., Budżet obywatelski w Polsce, Warszawa 2014.

Kubicki P., Ruchy miejskie w Polsce. Próba analizy, www.slideshare.net (dostęp 15.11.2016).

Kwiatkowska M., Sąy obywatelskie jako przykład demokracji partycypacyjnej, „Samorząd Terytorialny" 2013, nr 6.

Langton R., What is citizen participation, [w:] Citizen Participation in America: Esseys on the State of the Art, ed. R. Langton, Lexington 1977.

Łabędź K., Partycypacja obywatelska na poziomie lokalnym - formy $i$ ograniczenia, „Przegląd Politologiczny” 2015, nr 4.

Łukowski W., Partycypacja,czyli o trudnościach w dzieleniu się władza, „Zoon Politikon” 2012, nr 3.

Makowski G., Przeglad prawno-instytucjonalnych ram konsultacji społecznych na poziomie samorzadu terytorialnego, [w:] Prawo a partycypacja publiczna. Bilans monitoringu 2012, red. P. Sobiesiak-Penszko, Warszawa 2013.

Małecka-Łyszczek M., Partycypacja $w$ ramach public governance, [w:] Partycypacja społeczna w samorzadzie terytorialnym, red. B. Dolnicki, Warszawa 2014.

Megler L., Z liderami czy bez liderów? Partycypacja na przykładzie nowych ruchów miejskich, „Animacja Życia Publicznego” 2013, nr 3.

Michałowski S., Samorząd terytorialny a społeczeństwo obywatelskie, [w:] Samorzad terytorialny III Rzeczypospolitej. Dziesięć lat doświadczeń, red. S. Michałowski, Lublin 2002.

Miruć A., Obywatelska inicjatywa uchwałodawcza, „Samorząd Terytorialny” 2010, nr 1-2.

Mojkowski K., Pięć lat inicjatywy lokalnej. Porównanie przepisów dotyczacych inicjatywy lokalnej z praktyka ich stosowania w latach 2010-2014, www.masz głos.pl (dostęp 20.12.2016).

Mollo T., Konsultacje komunalne jako klasyczna forma partycypacji społecznej, [w:] Partycypacja społeczna w samorzadzie terytorialnym, red. B. Dolnicki, Warszawa 2014.

Nawrot B., Miejsce „inicjatyw niezależnych” na lokalnej scenie politycznej w Polsce, „Przegląd Politologiczny” 2009, nr 1.

Nawrot B., Postawy i zachowania mieszkańców wobec samorzadu terytorialnego na poziomie matych miast $i$ wsi, [w:] Władza lokalna a reforma samorzadowa $w$ Polsce, red. P. Dobrowolski, S. Wróbel, Katowice 1995.

Olech A., Kiedy mieszkańcy uczestnicza w podejmowaniu decyzji, [w:] Przepis na uczestnictwo. Diagnoza partycypacji publicznej w Polsce, red. A. Olech, t. II, Warszawa 2013.

Olech A., Kaźmierczak T., Modele partycypacji publicznej, [w:] Partycypacja publiczna. O uczestnictwie obywateli w życiu wspólnoty lokalnej, red. A. Olech, Warszawa 2011.

Olech A., Sobiesiak-Penszko P., Partycypacja publiczna w Polsce. Diagnoza i rekomendacje, numer specjalny, „Analizy i Opinie” 2013, nr 3. 
Olejniczak-Szałowska E., Członkostwo wspólnoty samorządowej, „Samorząd Terytorialny" 1996, nr 5, s. 8-11.

Orłowska-Bednarz M., Solectwo jako przykład demokracji bezpośredniej, [w:] Stan i perspektywy demokracji bezpośredniej w Polsce, red. M. Marczewska-Rytko, Lublin 2000.

Peisert A., Demokracja deliberatywna: utopia czy ratunek dla demokratycznych wartości, „Kultura Liberalna” 2010, nr 2(52).

Piasecki A. K., Inicjatywa obywatelska w praktyce politycznej III RP, „Państwo i Społeczeństwo" 2010, nr 2.

Podemski K., Uczestnictwo w życiu politycznym, [w:] Jednostka wobec władzy, red. M. Ziółkowski, B. Pawłowski, R. Drozdowski, Poznań 1994.

Rachwał M., Referenda w sprawie odwołania organu gminy przed uptywem kadencji-doświadczenia lat 2006-2010, [w:] Wieloaspektowość samorządności gminnej w Polsce, red. B. Nawrot, J. Pokładecki, Poznań 2011.

Rachwał M., Referenda w sprawie odwołania organu samorządu terytorialnego - doświadczenia lat 2010-2014, „Kwartalnik Naukowy OAP UW ePolitikon” 2014, nr 11.

Radiukiewicz A., O obywatelskości we współczesnym świecie. Kierunki zmian i przestrzenie rozwoju, „Zoon Politikon” 2012, nr 3.

Raport Kancelarii Prezydenta RP nt. referendów lokalnych, www.prezydent.pl (dostęp 21.12.2016).

Raport końcowy z badania efektywności mechanizmów konsultacji społecznych, 43/DPP/ PN/2009, Ministerstwo Pracy i Polityki Społecznej oraz MillwardBrown SMG/KRC, Warszawa 2011.

Regulski J., Samorządność i społeczeństwo obywatelskie - kilka pytań i wiele watpliwo$s c i$, „Samorząd Terytorialny” 2013, nr 3.

Rulka M., Próg frekwencyjny w gminnych referendach odwoławczych, „Infos” 2016, nr 17.

Schimanek T., Partycypacja obywatelska w społeczności lokalnej, Warszawa 2015.

Sidor M., Konsultacje spoleczne w największych polskich miastach: prawne aspekty - praktyczne zastosowanie, [w:] Partycypacja społeczna w samorzadzie terytorialnym, red. B. Dolnicki, Warszawa 2014.

Sroka J., Deliberacja i rządzenie wielopasmowe. Teoria i praktyka, Wrocław 2008.

Szczepański M.S., Cnoty i instytucje obywatelskie w społeczności lokalnej, Tychy 2001.

Sześciło D., Koncepcje ustawowego uregulowania budżetów obywatelskich (partycypacyjnych), Warszawa 2014, www.masz głos.pl (dostęp 14.11.2016).

Sześciło D., Konsultacje społeczne w gminie w świetle orzecznictwa sądów administracyjnych, ,Samorząd Terytorialny” 2014, nr 1-2.

Sztompka P., Zaufanie. Fundament społeczeństwa, Kraków 2007.

Waśkiewicz A., Dobro wspólne i społeczeństwo obywatelskie w teorii demokracji deliberatywnej i reprezentacji grupowej, [w:] Partycypacja obywatelska. Od teorii do praktyki społecznej, red. A. Przybylski i A. Giza, Warszawa 2014.

Węglarz B., Ewolucja lokalnej demokracji przedstawicielskiej w Polsce po 1989 roku, Kraków 2013.

Węglarz B., Referenda lokalne w sprawie odwołania organów jednostek samorzadu terytorialnego w czwartej kadencji (lata 2002-2006), „Samorząd Terytorialny” 2007, nr 7-8. 
Wróbel S., Miejskie ruchy polityczne. Wybrane zagadnienia, [w:] Od teorii do praktyki politycznej, red. M. Kołodziejczak, R. Rosicki, Poznań 2012.

Wróbel S., Powstanie i ewolucja miejskich ruchów politycznych. Przypadek miast górnośląkich, „Przegląd Politologiczny” 2005, nr 1.

Wyrok NSA z 21 listopada 2013 r., sygn. II OSK 1887/13.

Zaufanie w stosunkach międzyludzkich, BS/29/2014, Komunikat z badań CBOS, Warszawa 2014.

Zmiany $w$ psychologicznych profilach elektoratów partyjnych, BS/19/2011, Komunikat z badań CBOS, Warszawa 2011.

Żerkowska-Balas M., Kozaczuk A., Obywatele $i$ wybory, Warszawa 2013.

Żerkowska-Balas M., Zaremba M., Partycypacja nowych wyborców, Warszawa 2015, www.batory.org.pl (dostęp 15.11.2016).

\section{Jacek Pokładecki}

\section{Партиципация и локальная политическая система}

Реституция местного самоуправления в Польше является венцом начатого в 1990 году процесса децентрализации власти. Об эффективности этих перемен свидетельствует институализация местной власти, являющаяся в настоящее время важным элементом демократического государства. Местное самоуправление, как определенная форма публичной власти, объединяет локальное сообщество, одновременно детерминируя локальную политическую систему. Одним из его ключевых заданий является деятельность в области имплементации решений, влияющих на уровень жизни локального сообщества. Этот процесс осуществляется посредством оказания общественных услуг, целью которых является как общественное, так и экономическое развитие.

Ключевые слова: демократия, местное самоуправление, гражданское общество. 


\section{Jacek Pokładecki}

\section{Participation and the local political system}

In Poland the process of decentralization of power started in 1990. As a consequence it resulted in the restoration of local government. The efficiency and effectiveness of the decentralized political system is directly connected with the institution of local government, which is an important element of a democratic state. Local government is a special form of public authority, binding the local community and acting to merge local institutions into one functional unit, which determines the local political system. In addition, an important activity of political self-government is implementetion of the economic mission, attention to quality and living standards by providing public services, social and economic development.

Keywords: democracy, political system, local government, civic society. 